\title{
ANTYK CHRZEŚCIJAŃSKI W KAPLICZKACH PRZYDROŻNYCH
}

Trudno sobie wyobrazić nasz polski krajobraz bez przydrożych krzyży i kapliczek. Laden z narouów nie stworzył w tej dziedzinie nic równie pięknego, co rozmaitością 1 urodą formy harmonizowałoby 1epiej z otaczającą przyrodą. Te niepowtarzalne pomniki sztuki ludowej stoja nie tylko na rozstajach dróg wiejskich pośród "pól malowanych zbożem rozmaitem, /Wyzłacanych pszenica, posrebrzanych żytem", ale zdobią również miasta. Zatrzymują niejednokrotnie przechodnia na chwilę zadumy i modlitwy. Przypomnijmy tu chociażby sugestywny wiersz einigranta polskiego, Konstantego Gaszyńskiego, pt. "l'ęsknota za krajew"będący trawestacja znanego utworu A. Mickiewicza "Do $\mathrm{H}^{\mathrm{XxX}}$. Wezwanie do Neapolu. Nasladowanie z lioethego". Poeta roztacza przed czytelnikiem już nie uroki italskiej ziemi, lecz widzianą oczyma tęsknoty - ziemię polską, której nieodłącznym składnikiem są właśnie krzyże $i$ "święci z kamienia":

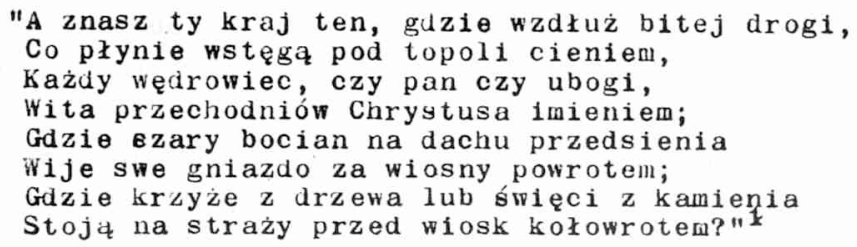

Do refleksji powyżsıych skłoniło mnie ciekawe, dwutomowe dzieło, wydane 1983 r.pt. "Kapliczki, Pigury 1 krzyże przydrożne na terenie diecezji tarnowskiej" pod red.ks. Jana Rzepy ${ }^{2}$. Jest ono

1. W. Cybulski, Odczyty o poezji polskiej w pierwszej połowie XIX wieku, I-II, Pozná́ 1870, 175.

2 Kapliczki, figury i krzyże przydrożne na terenie diecezji tarnowskiej. Schematyzin diecezji tarnowskiej 1983, red.ks. J. Rzepa, oprac. graficzne J. Matras, Tarnów 1983, t. 1: Teksty, ss. XXII+ 790 , t.2: Ilustracje, ss.XXII + 1477 rycin. 
w pewnym stopniu szczegółowszym rozwinięciem i uzupełnieniem innego analogicznego albumu "Kaplice 1 krzyże przydrożne w Polsce" w opracowaniu Tadeusza Seweryna ${ }^{3}$. Owe kapliczki stanowią nie tylko odbicie twórezego ducha $i$ artystycznych upodobań ludu, ale sq przede wszystkim wyrazem prostej wiary minionych pokoleń oraz, jak to pięknie wyraził jeden z redaktorów wyżej wymienionego dzieła, modlitwy ludu polskiego rzezane w drzewie, kute w kamieniu lub przelane na płótno czy papier. Ich twórcy bowiem pracę nad nimi traktowali jako droge do zbawienia, oddanie czci Bogu i świętym, jako rozmowę z Bogiem, podziękowanie za wysłuchanie prośby, wyraz pokuty lub spełnienie ślubu, prośbę o błogosławieństwo i obronę przed nieszczęściami, a wreszcie jako upamiętnienie waznych historycznych wydarzeń. Wznoszono je bowiem również z okazji zwyoięstw i klęsk narodowych, powstańczych zmagań czy zbiorowych egzekucji. Choć z jednej strony stanowią one swoistą formę katechezy kształtującej oblicze wspólnot danej okolicy, to z drugiej sa źródłen wielu legend, podań, wierzeń 1 zwyczajów ludowych.

Wydane dzieło jest świadectwem koncentrowania się poboźnośc1 i zwyczajów ludu południowej Polski wokół określonych postaci. Chociaż kapliczki i Pigury wznoszono już w średniowieczu, to jednak nie zarejestrowano na terenie diecezji tarnowskiej zabytków starszych od XVI w., z czego można wnloskować, że najstarsze z nich stawiano z drewna 1 nie przetrwały do naszych czasów/może na ich miejscu zbudowano nowe/. Pomijając przedstawienia osób Trójcy Świętej, AnioŁów i Matki Bożej, można w oparciu o wyżej wspomniane dzieło wskazać na terenie diecezji tarnowskiej imiona 146 zidentyfikowanych świętych, którym poza oficjalnym kultem w kościele, poświęcono dodatkowo przydrożną figurę, płaskorzezbę, czy obraz. W tym pokaźnym katalogu świętych czczonych na Podhalu, pojawiają się równieź, stosunkowo w dużej liczbie, iniona świętych żyjących 1 działających w starożytności chrześcijanskiej /I-VIII w./, wśród których największá popular-

3 T. Seweryi, Kapliczki 1 krzyze przydrożne w polsce, oprac. red. W. Filipowicz - W. Szubzda, Warszawa 1958, ss. 214 . 
nością cieszył sie umęczony na pocz. IV w. św. Florian, posiadadający na terenie diecezji tarnowskiej aż 118 wizerunków przydrożnych /65 posazgów, 25 figur, 24 płaskorzeźby, 4 obrazy/. Następnie pod względem ich ilóści wymienić należy kolejno: św. Mikołaja zm. ok. $350 \mathrm{r}$. $/ 54$ wizerunki - 5 posagów, 7 figur, 35 płaskorzeźb, 7 obrazów/, św. Barbarę zm. ok. 305 r. /41 wizerunków-- 5 posagów, 5 figur, 29 płaskorzeżb, 2 obrazy/, św. Agnieszkę zm. ok. 304 r. /37 wizerunków - 4 Pi gurki, 32 płaskorzeźby, 1 obraz/, św.Zofię z córkami żyjąca w II w. /36 wizerunków - 2 posągi, 5 figur, 25 płaskorzé́b, 4 obrazy/, św. Wawrzyńca zm. 258 r. /33 wizerunki 1 posag, 4 Pigury, 26 płaskorzeźb, 2 obrazy/, św. Marcina zm. 397 r. /27 wizerunków - 2 figurki, 23 płaskorzeźby. 2 obrazy/, św. Sebast1ana zm. ok. 305 r. /24 wizerunki - 2 posagi, 3 figurki, 12 płaskorzeźb, 7 obrazów/, św. Agatę zm. $251 / 24$ wizerunki - 1 P1gura, 19 płaskorzeźb, 4 obrazy/, św. Walentego zm. 269./23 wizerunki - 3 posągi, 1 ligurka, 17 płaskorzeźb, 2 obrazy/, św. Wiktorię zm. 251 r. /18 wizerunków - 17 płaskorzeźb, 1 obraz/, św. Teklę żyjącą w I w. /19 wizerunków - 5 posagów, 2 figurki, 10 płaskorzeźb, 2 obrazy/, św. Helenę zm. ok. $328 \mathrm{r}$ • / 15 wizerunków - 14 płaskorzeźb, 1 obraz/. Do starożytnych świętych posiadających tylko po kilka wizerunków przydrożnych nalezą: popularny w średniowieczu św. Błażej z Sebasty /9 wizerunków/; unęczony prawdopodobnie na pocz. IV w., uwazany za stróża zwierząt i patrona od chorób gardła, co znalazło odbicie w liytuale rzymskim z okresu przed soborem Wat. II, który zawierał formuły poświęcenia świec/zw. błażejkami/, chleba, wina, wody 1 owoców; św. Onufry, pustelnik z egipskiej Tebaidy /6 wizerunków/, żyjący w IV w.; św. Petronella /5 wizerunków/ nazwana przez Martyrologium kzymskie córká św. Piotra, umęczona w I w.; św. Dorota $/ 5$ wizerunków/, dziewica 1 męczenniczka z III w., patronka ogrodników, kwiaciarzy, górników, matek; św. Anastazja /5 wizerunków/, męczenniczka, zm. ok. $304 \mathrm{r}$. od średniowiecza czczona przez lud 1 wzywana podczas bólu głowy oraz patronka cenzury; ́́w. Apolonia $/ 4$ wizerunki/, nęczenniczka z III w•, czczona w Polsce od średniowiecza, do której zwracano się o ustąpienie bólu zębów, patronka "Regni Poloniae" według pontyfikałów krakowskich z XV w•; św. Łucja z Syrakuz /3 wizerunki/, umęczona prawdopodobnie za Dioklecjana, w średniowieczu uznawana za patronkę chorych na oczy; św. Waleria /3 wizerunki/ matka św. Gerwazego i Protazego, męczenniczka z II w॰; ́́w. Cecylia 
/2 wizerunk1/, jedna z najpopularniejszych rzymskich świętych, żyjaca na przeł. II 1 III w。 w Rzymie, w średniowieczu uznawana za patronkę muzyki kościelnej.

Po jednym wreszcie wizerunku posiadaja umęczona w I w. św. Domitylla, św. Teodor $i$ św. Teodozja umęczeni za Dioklecjana, św. Urban papież z 1. poł. III w. czczony w średniowieczu jako patron rolników i hodowców winorośli, związany ze zwyczajami ludowymi, pos1adajacy obok przydrożnego XIX-wiecznego posagu także stary obraz w murowanej kaplicy z XVII w., zwanej Pustelnia/.Iwkowa k• Brzeska/; św. Urszula, patronka miasta Kolonii i paryskiej Sorbony, wdzięczny temat ikonografil średniowiecznej, umęczona przez Germanów oraz Maria Egipcjanka, pustelnica, żyjąca przed VI wiekiem.

Wóród starożytnych świętych, których wizerunki widniejaz w przydrożnych kapliczkach osobną, choć nieliczną grupę stanowią ojcowie Kościoła: św. Benedykt - 7 wizerunków/1 posąg, 2 Pigurki, 4 płaskorzezby/, św. Grzegorz Wielki - 6 wizerunków/1 posąg, 5 płaskorzeźb/, św. Bazyli Wielki - 2 wizerunki /płaskorzeźby/ oraz po jednym wizerunku: św. Ambroży, św. Algustyn, św. Jan Chryzostom, św. Klemens Rzynski, św. Leon wielki, sw. Piotr Chryzolog, św. Polikarp.

Na szczególną uwagę zasługują zwłaszcza rzeźby z 2. poł.XVIII w. 4 niezidentyfikowanych Ojców Kościoła/jeden w papieskiej tiarze, trzech w zachodnich mitrach biskupich/w dworskiej kapliczce murowanej z 1873 r. werynii, pochodzące ze starego kościoła w Kolbuszowej. Warto przy tej okazji wspomnieć, że niektórzy z wyżej wymienionych ojców maja dedykowane sobie kościoły, przewaźnie z obrazami swych patronów w ołtarzu głównym, a mianowicie: św. Augustyn/Jamy wielkie, przeniesiony z Wadowic, XVIII w./, św. Grzegorz Wielki papież/Gorzejowa, przed. 1747 r. z obrazem patrona z 1698 r., wzmiankowanym $1747 \mathrm{r}$. jako łaskami słynųcy, a w bocznym ołtarzu obraz św. Augustyna z XVIII w./, św. Klemens Rzymski papież/Czermink. Mielca z $1630 \mathrm{r./}$, św. Antoni Pustelnik /Męcina Wielka, XVI w./, św. Marcin z Tours /parafie przeważnie XIII - XIV w., a aktualne kościoły: Czarny Potok 1755, Czermna 1520, Gnojnik 1380, Gromnik XV w., Grywałt XV w.; Lużna 1872, Liogilno 1578, Zawada k。 Tarnowa XV w., Ĺwiernik 1644, Wielopole Sikrzyńskie 1595 - 1722/.

Nalezy tu równiez wyıienić starożytnych świętych czczonych w Kościele Wschodnin, którzy w diecezji tarnowskiej posiadajazkilka dedykowanych sobie kościołow. Ma to głównie niejsce na terenach 
Łemkowszczyzny, gdzie dawne grekokatolickie cerkwie zamieniono pózniej na kościoły łacińskie. Do tych świętych należą popularni na Wschodzie patronowie chorych, lekarzy 1 kupców - św. Kosma 1 Damian Męcina wielka z dawna cerkwią grek okatolicka fundowaną przez Zygmunta I Starego w 1546, Banica 1797, Skwirtine 1837, Tylicz 1738, Wojkowa 1792, Małastów 1743/, umęczony na przeł. III i IVw., Dymitr z Salonik /Kościoły: Bodahi 1902, Brunary 1764, Gładyszów 1789, Złockie 1841 / oraz męczennicaka z 2.poł. II w. św. Parascewa/Kwiatoń 2. poł. VII w., Nowica $1806 /$.

II

Druga obszerniejsza cz\&́ś artykułu bęuzie zawierała informacje biograficzne 13 najczęściej występujących starożytnych świętych/do 15 wizerunków/ oraz krótki zarys ich kultu w starożytności i średniowieczu, co pozwoli wskazać na przyczyny ich przydrożnej obecności na Podhalu. Przy każdym z nich przytoczona zostanie in extenso wypowiedź Martyrologium rzymskiego, które chociaz w ostatecznej formie pochodzi z późniejszego okresu /1584/, to jednak ujmuje i wyraża stara, oficjalną tradycję Kościoła o danym świętym.

1. Sw. Florian z Lorch, utopiony za wiarę na pocz. IV w. w rzece Énns - to najczęściej występujący przy drogach lub na placach diecezji tarnowskiej starożytny święty. Nie istnieją o nim współczesne mu źródła, lecz jego męczeństwo opisuje dopiero, pochodząca z VIII w., "Passio S. Floriani"4. W średniowieczu cieszył się w Europie Zachodniej /Górna Austria, w diecezjach - salzburskiej, praskiej, wiedeńskiej, pasawsikiej, mogunckiej/ ozywionym kulten, czczony jako obrońca przed ogniem i powodziami. Stamtąd kult jego przeniósł się do Polski, gazie wzwógł się zwłaszcza po sprawadzeniu jego relikwii w 1184 r. do Krakowa. Wtedy właśnie poświęcono mu kilkanaście kościołów/m.in.

4 MGL Scriptores rerum Herovingicarum $3,65-71$, oprac. S. Longosz, Męczeństwo św. Floriana. istęp, przekłal/A. Prawecki/, Komentarz, Voxp 4/1984/Z, 6-7, 411-429; Acta SS, Naii I, Parisiis 1866, 467471; BS V 934-937; P. Skarga, Lywoty Swiętych Starego i Nowego Zakonu na każdy dżié przez cały rok, I-IV, Kraków 1933-1936, 237240; W. Zaleski, Şięci na każy dzień, Lódź 1984, 227-228; Martyrologium Romanum, ed. H. Delehaye et socil, Bruxeiles 1940, 159, tłun. P. Turbak/Martyrologiur Iizymskie, Kraków 1967/132: "W Lorch, w dawnym Norykum/Noricum - Ripense/ świętego Floriana, męczennika, za panowania Diokleejana z rozkazu namiestnika Akwi- 
w Krakowie 1184, w Koprzywnicy 1185, Wąchocku, Sulejowie/. Kult ten znów się ożywił po pożarze w 1528 r. części Krakowa/Kleparz/, zwanej wcześniej od św. Floriana - Florencją, z której jednał ocalał kościół św. Floriana. Wówczas poświęcono florianowi również wieie kapliczek, posłgów i obrazów jako obrońcy przed ogniem. ren prawdopodobnie wzgląd oraz sasiedztwo Krakowa zdecydowały, że w diecezji tarnowskiej dedykowano Florianowi w miçdzyczasie, jak już wspomniano, aż 118 przydrożnych wizerunków, ale zaledwie jeden aktualnie istniejący kościół/Uszew 1866, z ołrazen w ołtarzu głównym/. Swięty ten uważany był za patrona miast i miejscowości, na rynkach których wznoszono mu często Pigury fundowane z miejskich składek/np. Biecz 1902 Bobowa 1800, Brzesko 1731, Czchów XVIII $\varpi_{\bullet}$, Limanowa 1830, Lipnica 1837, Muszyna 1. poł.XIX w., Ryglice 1830, Ștary Sącz XVIII/XIX w॰, Tuchów 1781, Tymbark 1870, Zakliczyn XIX w., Zbylitowska Góra 1767 , Zabno 1883/. Na szczególną uwagę zasługuje tu wzniesiona w $1843 \mathrm{r}$., za staraniem burmistrza Cyryla Dorożewskiego, figura na rynku Wojnicza z jego herbem z Pundacji miasta $i$ Korpusu Oficerskiego 10 c.k. pułku huzarów dla upamiętnienia 1831 roku. Dziś czczony jest głównie jako patron strazaków ${ }^{5}$.

\section{Sw. Mikołaj - to żyjący na przeł. III i IV w. bp Miry,} osnuty legendami przekazywanymi ustnie. Brak o nim współczesnych mu źródeł, choć jego podpis miał widnieś pod dokumentami I Soboru Nicejskiego /325/. Pierwsze spisane informacje o jego życiu i cudach pochodzą dopiero z IX w., z anonimowego "Vita per Michaeler" $\mathbf{i}$ z uło-. żonej w latach 842-846 przez patriarchę Konstantynopola, Metodego, kompilacji "Methodius ad Theodorum"6. Był to jeden z najpopularniejšych świętych chrześcijaństwa. pierwsze ślady jego kultu pojawiają

Iina wrzucono go do rzeki Enns z kamieniem u szyi" / + 304/.

5 Por. K. Dobrowolski, Dzieje kultu św. Floriana w Polsce do połowy XVI wieku, irarszawa 1923; W. Schenk, Kult Świętych w Polsce, rirK $13 / 1966 / \mathrm{z}, 4,86-88$.

6 por. G. Anrich, Ilagios Nikolaos. Der heilige Nikolaos in der griechischen Kirche, TU 2, Leipzig-Berlin 1913-1917, Bd. 1, 111150, Bd. 2, 261-288; BS IX 923-948; Skarga IV 383-392; H. FrosF. Sowa, Twoje imię. Przewounik ononastyczno-hagiograficzny, Kraków 1975, 353-354; Laleski 754-757; G. Lananiri, San Nicola, Bari 1972;B.A. Uspienski, Kult św. Mikołaja na lusi, Lublin 1985; Martyrologium liomanum 568-569, Turbak 347: "W Mirze, stolicy Licji, zejście św. Mikołaja, biskupa i wyznawcy. Z licznych jego 
się WI w. wirze, która stáła się celem pielgrzymek oraz w Konstantynopolu, gdzie cesarz Justynian zbudował mu jedną z najwspanialszych bazylik/Blachernes/. W IX w. było juźkilka jego kościołów w Fzynie, głównie z inicjatywy papieża Mikołaja I /858-867/. Jego kult w Niemezech w X w. szerzyła cesarzowa Teofano, a we Francji i Anglii - żeglarze normandzcy. Do Aalszego rozpowszechnienia kultu św. Mikołaja w Europie przyczyniło się sprowadzenie w 1087 r.jego relikwii do Bari i wybudowanie mu tam okazałej bazyliki. Wkrótce jego kult ogarnął cały chrześcijański Wschód, zajmując w niektórych jego ozęściach trzecie miejsce po Bogarodzicy i św. Janie Chrzcicielu, na Zachodzie zaś uznano go za jednego z czternastu wspomożycie1i, opiekuna dzieci, zeglarzy, kupców, piekarzy, więźniów, patrona niektórych cechów, na Rusi natomiast uważano za opiekuna bydła, uprawy roli i pszczelarzy. Nic dziwnego, ze tak rozpowszechniony kult dotarł równiéz do Polski, gáównie poprzez szlaki hanulowe, díla których stał się patronen. Pou jego wezwaniem istnieje w Polsce aż 327 kościołów/zajmuje tilejsce po św. Janie Chrzcicielu, a przed św. Piotrem i Pawłen/s Posiada ponado tysiące obrazów i Pigur, a nawet sanktuaria, jak na przykład do XVI w. na Pomorzu Zachodniru w okolicy Koszalina, a do XIX w. w Pierściu na Śląsku Cieszyriskim ${ }^{7}$. WV orbicie tak żywego kultu św. Mikołaja znalazła się równié̇ diecezja tarnowska, w której do chwili obecnej istrieje 17 kościołów pou jego wezwaniem, pochodzçcych w większości z XIV - XVIII w。/najstarszy w Bochni sprzed 1250 r., Lęg Tarnowski - 2. poł. XIV w。/, a także liczne kapliczki przytrozne. Geneza tych ostatnich mieści się niewatpliwie w ramaci ogólnego kultu, szerzonego przez kościoły parafialne, jak $i$ związanych z jego osobaz zwyczajów ludowych.

3. Sw. Barbara. Nie miejszymi legendami jest osnuta wielce czezona i bardzo popularna we wschodnim i zachodnim chrześcijanstwie św. Barbara, która luiała byé zamisnięta w wiezy, a nastepnie ścięta

cudów zasługruje na szczegolną uwage to, ze będac daleko ukazał się cesarzowi Konstantynowi i upomnieniami oraz grozbari skłonił go do ułaskawienia niektóryci oskarżonych, którzy wzywali jego/Mikotaja/ poinocy" $/+$ ok. $350 /$.

7 o jego kulcie w Polsce por. B. Kumor, Powstanie i rozwój sieci parafialing w hatopolsce potutniowej, PK $6 / 1963 / 458-460$; M. Limanowski, Sw. kikotaj opiekun iró f hanulowych przy końcu wieków średnich /XV 1 XVI w./ w Księstwie Litewskia, w: "Zjazd Słowiańskicin Geografów i Lt nografów" 2/1930/283-824. 
za wiare przez swego ojca podczas prześladowá za Diokledjana. Nieznamy daty ani miejsca jej śmierci, jak rómiez nie posiadamy żadnych źródłowych informacji patrystycznych na jej temat. Według pózniejszych legendarnych zywotów w językach: greckim, syryjskim, koptyjskim, ormiańskim, chaldejskim 1 łacińskim, miała nawet korespondować z Orygenesem, a Grzegorz Wielki /590-604/ zanim został papieżem miał się chętnie modlić, jak opowiada jego późniejszy biograp, w jej rzymskim oratorium ${ }^{8}$. Można więc wnioskować, że w IX wieku istniały w Rymie jej sanktuaria ${ }^{9}$. Piernsze ślady jej kultu na Wschodzie pojawiają sie w IV $w_{\text {. }}$ /przyjęcie jej imienia jako tytułuklasztoru w Edessie, a potem bazyliki koptyjskiej Kairze z VII w./. W VIII w. umieszczono jej święto walendarzu Kościołów greckiego i syryjskiego pod data 4 grudnia. Do spopularyzowania jej kultu na Zachodzie przyczyniło sięMenologium Metafrasta /X w./, choć już w IX w. jej 1mię było umieszczane we wszystkich martyrologiach środkowej Italii, a wcześniej, bo w VIII w. bp Trewiru Adam napisał "Laudatio sanctae Barbarae". Cesarz Justynian miał sprowadzić w VI w. jej relikwie do Konstantynopola, skąd w 1202 r. miano je przenieść do Wenecji, chociaz egipscy chrześcijanie twierdzą, że znajdują się one w starym Kairo. Herma z jej czaszką była podobno równiez w Czerwińsku. Na Zachodzie czczono ja we Flandri1, Nadreni1, w Austri1, Czechach jako patronke dobrej śmierci zwłaszcza tam, gdzie nagle groziła, a więc wśród górników, hutników, marynarzy 1 więźniów. Kult śn. Barbary ogarną równiez Polskę, w której czczono ją głównie jako patronkę górników 1 dobrej śmierci 10. Najstarsze ślady obchodów jej święta spotykamy w zbiorach katedry krakowskiej, m.in. w "Modlitewniku Gertrudy", córki Mieszka II, zachowała się pierwsza wzmianka o jej świecie/4 XII/

8 Por. Joannes Diaconus, Vita Gregori1 Magni IV 89, PL 75, 234 B: "Oratorio sanctae Barbarae, ubi Gregorius laudes Domino celebrare solebat".

9 Por. Liber Pontificalis, ed. L. Duchesne, Paris 1955-1959, I, 50 1116.

10 Por. Acta SS. Junii VI 678; Skarga IV 375-377; BS II 760-767; EK II 14-20; Fros-Sowa, 81-82; Zalesk1 751-753; J. Górecka, Kult liturgiczny sw. Barbary w diecezji krakowskiej do końca XVI wieku, w: Studia z dziejów liturgil w Polsce, Lublin 1976, II, 297355; Martyrologium Romanum 564, Turbak 345: "W Nikomedi1 św, Barbary, panny 1 męczenniczki. W czasie prześladowania Maksymiana dręczono ja srodze we więzieniu,przypalano pochodniami, obcięto jej piersi i męczono różnymi sposobami; wońcu ścięta mieczem dokonała swego męczeństwa" / IV w./. 
oraz w "Benedykcjonale krakowskim" /pocz. XII w./ formuły błogosławieństw św. Barbary, a także w Kalendarzu kapituły krakowskiej z 1224 roku. Najstarszy dedykowany jej kościół zbudowano w Polsce w 1262 r. w Borzygniewie a do końca XVII w. było ich 104 /ołtarzy 165/, głównie na Sląsku, Pomorzu oraz w Małopolsce, gdzie tytuł Barbary noszą 22 kościoły, 20 kaplic i 59 ołtarzy z najstarszym z XI w. w Solcu k. Opola Lubelskiego. Na tym tle zrozumiała staje się równiez tak duźa liczba jej przydrożnych wizerunków w diecezji tarnowskiej/41/, choć aktualnie posiada tutaj tylko jeden kościól / w miejscowości Szyk/ sobie dedykowany w latach $1358-1373$ z fundacji rycerskiej.

Do jej najstarszych przydrożnych wizerunków należy niewątpliwie XV-wieczna kapliczka w Czchowie, w której widnieje jej gotycka rzeźba obok św. Doroty.

4. Sw. Agnieszka - to dalsza starożytna święta, umęczona prawdopodobnie za Dioklecjana, występująca często w kapliczkach przydrożnych diecezji tarnowskiej. Należy ona również do popularnych świętych starożytności chrześcijańskiej. Czczono ją już w IV w., o czym świadczą jej wizerunki w katakumbach ów. Pamfila oraz Komodilli, napisy wokół miejsca jej spoczynku w katakumbach, które od niej wzięły nazwę, a także wybudowana nad nimi 337 r. w Rymie bazylika pod jej wezwaniem przez Konstancję, córkę Konstantyna Wielkiego. Wspominają o niej równieź źródła pisane, a mianowicie najstarsze z nich "Depositio martyrum"/354/ ustalające jej uroczystość na 21 stycznia oraz epitafium ku jej czci ułożone przez papieża,św。 Damazego /366$384 / 11$, napisany w $377 \mathrm{r}$. traktat św. Ambroźego "De virginibus"12 1 "Peristephanon" Prudencjusza ${ }^{13}$. Męczennicę tę wysławiają w mowach także późniejsi ojcowie Kościoła: św. Hieronim ${ }^{14}$, św. Augustyn ${ }^{15}$,

11 Por. Depositio martyrum, Kirch 544: "XII Kal, Peb•,Agnetis in Nomentana"; A. Ferrua, Epigrammata Damasiana, Città del Vaticano $1942,176$.

12 De virginibus $2,5-9$ i 14, 19, PL 16, 200-202 1 205. Przek $¥$ ad tych miejsc oraz epitafium Damazego por. A. Bober, Antologia Patrystyczna, Kraków 1965, 164-166 i 552; Ambrożemu przypisywano też niesłusznie hymn ku czci św. Agnieszki "Agnes beatae virginis"/PL $17,1249 /$.

13 Peristephanon XIV, CCL 126, 386-389, PSP 43, 293-296.

14 Epistola 130, 5 /Ad Demetriaden z $414 \mathrm{r} . /$, PL 22, 1109, tłum. J. Czuj, Sw。 Hieronim, Listy, III, Warszawa 1954, 308.

15 Sermo 273, 6, PL 38, 1250; Sermo 354, 5, PL 39, 1565. 
św. Maksym z Turynu ${ }^{16}$ oraz św. Grzegorz Wielki, papież ${ }^{17}$ Jej kult promieniował później, głównie w średniowieczu,z Rzymu na Europę, stając się przedmiotem bogatej ikonografii. Kówniez w Polsce od średniowiecza znane było jej imię,zwłaszcza na Śląsku ${ }^{18}$ ale jakiegoś specjalnego kultu, poza nadawaniem jej imienia dzieciom, nigdy nie osıagnęła. Pierwsze znane jej przedstamienie wraz ze św. Katarzyną pochodzi z 2. poł. XIII w. wajstarszym zachowanym fragmencie obrazu sztalugowego /Kuria w Krakowie/. W diecezji tarnowskiej nie ma obecnie zadnego dedykowanego sobie kościoła. Tym bardziej więc dziwi duża ilość jej przydrożnych wizerunków, których źródło zdaje sie spoczywać głównie w 1 mionach fundatorek.

5. Sw. Zofia z córkami - to następna wczesnochrześcijańska postać licząca 37 wizerunków w kapliczkach przydroznych. W diecezj1 tarnowskiej posiada tylko jeden dedykowany sobie kościól pomocniczy /Bobowa/, zbudowany w 2. poł. XV W. z XVIII-wiecznym obrazem w ołtarzu głównym. Brak jest wczesnych patrystycznych źródeł o tej postaci. Nie znamy ani czasu, ani miejsca jej męczeństwa. o niej i jej córkach /Fides, Spes, Caritas/ wspomina dopiero "Notula oleorum" z VII w. oraz 2 itineraria rzymskie. Według powstałej w VII-VIII w。 Pass1o/w języku greckim, racińskim, syryjskim i armeńsḳim/miała umrzeć za Trajana śmiercią naturalną, w trzy dn1 po męczeństwie swych córek. Miały być one pochowane w katakumbach św. Pankracego,

16 Sermo 56 /In natali S. Agnetis/, PL 57, 643-648.

17 In Evangelia homiliae I 11 i 12, PL 76, 1114-1123.

18 H. Neuling, Schlesiens Kirchorte und ihre kirchlichen Stiftungen bis zum Ausgange des Mittelalters2, Wrocław 1902, 28-29; W. Stroka, Pieśń o św. Agnieszce, Kraków 1901; BS I 382-410; EK I 179180; Fros-Sowa 38; Zaleski 45-46; Skarga I 145-152; Martyrologium Romanum 107, Turbak 41: "W Rzynie cierpienie świętej Agnieszki, panny 1 megczenniczki. Z rozkazu prefekta miasta Symfroniusza wrzucono ją wogień. Gdy ona zgasiła go modlitwa, zgładzono ją mieczem. Tak pisze o niej święty Hieronim: "Wszystkie ludy, a przede wszystkim gminy chrześcijańskie, wysławiają życte Agnieszki słowem i pismem, bo ona i słabość młodocianego wieku i tyrana zwyciężyła, a sławę czystości uświęciła męczeństwem" $/+$ ok. $305 /$. 
przy Via Aurelia, guzie przez długie wieki pokazywano ich relikwie. Nie ma równiez zasadniczych powodów, aby imiona jej córek były interpretowane wyłącznie jako personifikacje cnót teologicznych,gdyz zachowały się o nich pewne wzmianki historyczne. Papiez Paweł I /756-767/ miał przenieść ich relikwie do wybudowanego przez siebie kościoła San Silvestro in Capite, w którym marmurowy kalendarz wyznaczał ich święto na 30 września. W średniowieczu kult matki 1 jej córek rozprzestrzenił się w całej Europie, docierając równieź do Polski, gdzie popularne stało się przede wszystkim jej imię. Z imieniem tym 1 dniem św. Zofii związanych jest wiele przysłów 1 zwyczajów, co mogło być zasadniczym źródłem jej popularności również wapliczkach przydrożnych ${ }^{19}$. Sam zresztą temat trzech umęczonych za wiarę córek $i$ umierającej z tęsknoty za nimi matki był wdzięcznym przedmiotem dla ikonograpil.

6. Sw. Wawrzyniec diakon, spalony za wiare na kracie 20 podezas prześladowania Waleriana /258/. Akta jego męczeństwa, jeśli w ogóle istniały, zaginęły dość wcześnie, ale pamięć o okrutnym rodzaju jego męczeństwa przekazywana była przez różne Passiones i legendy hagiograficzne 21 oraz utrwalona przez kilku ojców Kościoła, np. papieża Damazego, który ułożył mu specjalne epitafium ${ }^{22}$, św。Ambrożego, autora kilku wzmianek oraz hymnu ku jego czci ${ }^{23}$. Specjalne mowy lub

19 Por. BHL 2966-2973; BS XI 1277-1280; Skarga III 359-363; DACL XI 2753-2758; LThK IX 886-887; Fros-Sowa 468-469; Zaleski 253-254; Martyrologium Komanum 318 i 428, Turbak 284: "W Rzymie świętej Zopii wdowy, matki świçtych panien 1 męczenniczek Wiary, Nadziei i Miłości"/II w. ?/.

20 Por. Franchi de Cavalieri, San Lorenzo e 11 supplizio della crat1cola, RQ 14/1950/159-170; BS VIII 108-121; Skarga III 260-265; Fros-Sowa 448-449; Zaleski 459-461; Martyrologium Romanum 332, Turbak 229: "W Rzymie, przy drodze Tyburtyńskiej, podczas prześladowania Waleriana, zejście św. Wawrzyńca archidiakona. Wycierpiał wiele w więzieniu, biczowanie kijami i knutami ołowianymi oraz przypiekanie rozpalonymi blachami. W końcu pieczony na zelaznej kracie zakończył męczeństwo swoje. Święty fipolit wraz z Justynem kapłanem pogrzebał jego ciało na cmentarzu Cyriak 1 na polu Werańsk1m" / $258 /$.

21 Por. H. Delehaye, Recherches sur le légendier romain, AB 51/1933/ $34-98$, zwł. $49 \mathrm{nn}$.

22 A. Ferrua, Epigrammata Danasiana, 166-168.

23 Hymnus, PL 17, 1254-1255; De officils I 41, II 28; Epistola 37 , 36-37, PL 16, 90-92, 149-150, 1139 . 
wiersze poświęcili mu także św. Augustyn, Prudencjusz, św. Piotr Chryzolog, św. Leon Wielki i św. Maksym z Turynu ${ }^{24}$. Juź w 1. poł. IV w. obchodzono w Rzymie jego święto. Późniejsze sakramentarium Leonianum posiada aż 14 formularzy na jego uroczystość. Imię Wawrzyńca wpisano również szybko do rzymskiego kanonu mszalnego, a jego grób, nad którym Konstantyn Wielki zbudował bazylikę, stał się wkrótce celem pielgrzymek. Popularność 1 kult św. Wawrzyńca kwitł nadal w średniowieczu, szczególnie na Zachodzie, gdzie czczono go jako patrona ubogich, piekarzy 1 kucharzy oraz wzywano podezas pożarów 1 chorób reumatycznych. Wyrazem jego popularności była również duża ilość dedykowanych mu kośc1ołów. W samym Rzymie było ich kilkanácie/dzisiaj 6/. Popularność ta dotarła $i$ do polski, gdzie czczono go m.in. jako patrona pszczelarzy oraz dedykowano mu ponad 100 kościołów, wśród których są nawet sanktuaria/w Dolistowie, Rozpocinie, na Śnieżce/25. W diecezjl tarnowskiej pod jego wezwaniem istnieja 4 zbudowane w XII-XV w. kościoły/Biegonice, Cerekiew, Wojnicz, Zagórzany/, a najstarszy z nich w Biegonicach wzniesiony w 1269 r. z fundacj1 błog. K1ng1. Wzywanie go jako protektora przed pożarami oraz patrona piekarzy 1 kucharzy zdaje się być zasadniczym źródłem częstotlíośc1 jego występowania w kapliczkach przydroźnych, chociaż imie jego nadawano dzieciom stosunkowo rzadko.

7. Sw. Marcin biskup Tours - to kolejna wczesnochrześcijańska postać spotykana często w kapliczkach przydroznych południowej Polski. Był on jednym z plerwszych świętych niemęczenników, któremu juz niedługo po śmierci oddawano publiczną cześć w kościele, a jego grób stał się w średniowieczu sanktuarium i celem pielgrzymek 26 . Jego

24 Augustinus, Sermones 302-305, PL 38, 1385-1400; Prudent1us, Peristephanon, II, CCL 126, 257-277, PSP 43, 210-223; Petrus Chrysologus, Sermo 125, PL 52, 565-567; Leo Magnus, Sermo 85, PL 54, 486; Maximus Torinensis, Homilia 75, PL 57, 679-680.

250 jego kulcie w Polsce por. W. Schenk, Kult Swiętych w Polsce, art.cyt., 82 .

26 Por. E. Delaruelle, La spiritualité des pèlerinages à Saint-Martin de Tours du ve au $x^{e}$ siecle,w: Convegni del Centro di Studi sulla spiritualita medievale, IV, Todi 1963, 199-243; BS VIII 1248-1291; Skarga IV 227-240; Fros-Sowa 332-333; Zalesk1 696-699; Martyrologium liomanum, 'lurbak 322: "W Tours, we Francj1, zejście świętego Marcina, biskupa 1 wyznawcy. Życie jego tak bardzo jaśniało blaskiem cnót, że swoimi zasługami wskrzesił trzech umarŁyci" / $+397 /$. 
popularność w świecie chrześcijańskim ugruntowały wcześnie pisane życiorysy prozą lub wierszem przez takich autorów, jak Sulpicjusz Sewer /pocz. V w./27, Paulin z Périgueux /ok. $470 \mathrm{r} \cdot /{ }^{28}$, Wenancjusz Fortunatus /2. poł. VI w. $/ 29$, Sydontusz Apolinary /ok $478 \mathrm{r} \cdot /^{30}$ 1 św. Grzegorz z Tours $/ 594 \mathrm{r} \cdot /^{31}$. W Galii stał się sławny zaraz po śmierci, a Tours - miejsce jego grobu - jednym z najbardziej odwiedzanych miast średniowi ecza, do którego pielgrzymowali: Chlodwik, Klotylda, Chlotar, Karol Wielki, prawle wszyscy Merowingowie, św. Ludwik IX, Joanna d'Arc, kard. Giuseppe Roncalli, z Polaków-św. Wojciech 1 inni. Czczono go tez poprzez dedykowanie mu kościołó /we Francj1 poświęcono mu.3.672 parafie/ oraz wznoszenie mu pomników i kaplic; najstarszy jego wizerunek pochodzi z VI w. z mozalki w bazylice Sant'Apollinare Nuovo w Rawennie. Popularność ta dotarła 1 do Polski, gdzie szczególnie w średnioxieczu stał się jednym z najbardziej znanych 1 czczonych świętych ${ }^{32}$. Posiadał wówczas w Polsce pod swym wezwaniem 220 kościołów/obecnie 196/, a jego postać osnuta wielu przysłowiani $i$ związanymi z nią zwyczajami, znalazła sle nawet w herbach kilku miast polskich/np. Pacanowa/. Jego śrięto/11 XI/ przez kilka wieków było w Polsce obowiazujące. Czczony był jako patron miłosierdzia i biednych, w ikonografii przedstawiany womencie oddawania ubogiemu połowy swego płaszcza. W diecezji tarnowskiej posiada obecnie 10 /zbudowanych przeważnie w średniowieczu/ kościołów i kaplic. Uzasadnienia więc jego częstej obecności w przydrożnych kapliczkach należy szukać w popularnoścl kultu tego świętego w Kościele.

8. Sw. Sebastian - to od starożytności do XVI w. również jeden z najbardziej popularnych świętych w Europie, trzeci patron Rzymu. Według Passio 33 napisanej w poł. V w. przez anonimowego autora oraz

27 Vita S. Martini Turonensis, $\mathrm{SCh} 133$, tłum. W. Woźniak, Żywot świętego Marcina, Lublin 1985, mps BKUL.

28 De vita S. Martini libri VI, CSEL 16/1, 17-159.

29 De vita S. Martini libri IV, $\mathrm{PL} 88,363-426$.

30 Épistola IV 18, PL 58, 603.

31 De miraculis S. Martini episcopi libri IV, PL 71, 913, 1010.

32 G. Karolewicz, Kult św. Marcina w Polsce do schyłku XVI wieku, STV 8/1970/421-445.

33 Passio S. Sebastiani, PL 17, 1111-1150; BS XI 773-801; Skarga I 137-145; Fros-Sowa 408-409; Zaleski 44-45. 
anonimowej wzmianki w Depositio martyrum $/ 354 /^{34}$ i ambrozjańskiej informacji w "Komentarzu do Psalmu 118"35, miał byé jako młody żołnierz przeszyty za wiarę strzałami, wrzucony do Cloaca Maxima, a następnie pochowany przy Via Appia, skąd od jego grobu przybrały swą nazwę katakumby 1 bazylika św. Sebastiana. Jego imię umieszczane często razen z papieżem Fabianem wyinieniaja najstarsze kalendarze, martyrologia 1 sakramentarze ${ }^{36}$. W średniowieczu wzywany by czesto jako patron chroniący od epidemii 1 opiekun rycerzy, myśliwych, strażników, a nawet kamieniarzy 1 ogrodników. Postać zaś Sebastiana jako młodzieńca ginącego od strzał stała się wdzięcznym tematem dla artystów. Jego kult był równieź źywy w dawnej Polsce ${ }^{37}$, gdzie poświęcono mu wiele kościołów, ołtarzy i figur, a także utworzono liczne przysłowia zwiazzane z jego osobaz $\mathbf{i}$ świętem/20 I/. Ten zywy kult znalazł tez odzwierciedlenie na terenie diecezji tarnowskiej, gdzie aktualnie istnieją 3 dedykowane mu kościoły/Strzelce W., Ilkowice, Wielopole Skrzyńskie/ z obrazami lub posągan1 w głównych ołtarzach z XVII-XIX w., a w jednym z nich/w Wielopolu Skrzyńskim/ nawet rokokowy relikwiarzyk z XVIII wieku. Jego liczne wizerunki przydrożne /24/znajdują swe uzasadnienie zapewne w ogólnokościelnym kulcie oraz w przekonaniu, iź chronił on przed występującymi w średniowieczu epidemiami.

9. Sw. Agata - to wczesnochrześcijańska święta spotykana często w przydroźnych kapliczkach Podkarpacia. Choć jej kult był bardzo popularny na Zachodzie, szczegúlnie w Katanii, czego dowodem jest od V w. obecność jej ỉilenia w rzymskim, ambrozjańskim i raweńskim

34 Depositio martyrum, ed. R. Valentini - G. Zucchetti, Codice topografico della Citta di Roma, II, Roma 1950, 17: "XIII Kal. Peb. Fabiani in Callixti et Sebastiani ad Catacumbas".

35 Commentarius in Psalmum 118, PL 15, 1574.

36 Por. Martyrologium Romanum 27, Turbak 40: "W Rzynie św. Fabiana, papieża 1 męczennika /... / Również w Rzymie, w katakumbach, św. Sebastiana, męczennika. Za parowanta cesarza Dioklecjana był dowódcą pierwszej kohorty. Za wyznawante wiary chrześcijańskiej zołnierze przywiazzali go do pala na środku placu ćwiczeń 1 zasypali strzałái. W końcu tak długo bili go rózgami, aź wyzionął ducha" $/+288 /$.

37 Por. W. Baranowsk $1, Z$ badań nad katolicyzmem ludowym okresu pouwłaszczeniowego, w: "Zeszyty Naukowe Uniwersytetu Lódzkiego" I, z. $63,1969,89-90$. 
kanonie inszalnym oraz duża llość dedykowanych jej kościołów, to konkretne źródłowe informacje o jej życiu są bardzo późne i skąpe. Według sporządzonej dopiero w 2. poł. V w. lacińskiej i greckiej Passio, miała jako dziewica po różorodnych cierpieniach /m.in. oddanie jej do domu publicznego, obcięcie jej piersi/ zginąć w Katanil podczas prześladowania Decjusza $/ 5$ II $251 / 38$. Informacje te powtarzają o niej późniejsze martyrologia ${ }^{39}$. o starożytnym kulcie 1 popularności Agaty świadcza ponadto przypisywany Damazemu hymn ${ }^{40}$, mozalka w Kawennie w bazylice Sant'Apollinare Nuovo /VI w./ oraz kościoły fundowane ku jej czci przez papieży, jak bazyl1ka poświęcona jej przez papieża Symmacha $/ 498-514 / 41$, wprowadzenie jej relikwi ok. 593 r. do poświęconego jej poariańskiego kościoła m rzymskiej Suburze przez papieza Grzegorza Wielkiego /590-604/42 orazkościół wznies1ony dla niej ok. $725 \mathrm{r}$. przez papieża Grzegorza II/715-731/ na Zatybrzu obok bazyliki św. Chryzogona ${ }^{43}$. W średniowieczu posiadała w Rymie ponad 10 kościołów, na sycylii zaś czczono ją, m.in. jako opiekunkę chroniącą przed ogniem $i$ wybuchami Etny. Postać natomiast dziewicy umęczonej w tak wyrafinowany sposób była częstym przedmiotem twórczości artystów. Kult jej objął wkrótce całą Italię, Francję i Niemcy. Równiéz w Polsce od średniowiecza, szczególnie od XIII w., posługiwano się jej imieniem $\mathbf{i}$ czczono ją jako patronkę od ognia

38 Por. Acta SS. Februarii I 597-626; Skarga I 244-250; BS I 320-335; LThK I 184; Fros-Sowa 37; Zaleski 70-72.

39 Martyrolozium Hieronymianum/ed. Delehaye, Bruxelles 1937/ nia ja kilkakrotnie /5 II, 12 i 25 VII, 5'V, 6 XII/. Martyrologium Romanum 47, Turbak 54: "iV Katanii, na Sycylii, rocznica zgonu świętej Agaty, panny $i$ męczenniczki. Za panowania Decjusza z rozkazu sędziego Kwinkcjana bito ją po twarzy, wtrącono do więzienia, rozciągano na katowni, wykręcano jej członk1, obcięto piersi, tarzano ja po skorupach i żarzących się węglach. Skończyła życie we więzieniu wśród modlitwy"/III w./.

40 Por. Carmen 30: "Martyr1s ecce dies Agathae", PL 13, 403-405. 41 Liber Pontificalis, I, ed. L. Duchesne, Paris' 1866, 267.

42 Dialogi III 30, PL 77, 288, PSP 2, 137; Epistolae I 54, PL 77, 516 /IV 19, CCL 140, 237/: "ecclesia S. Agathae sita in Subura, quae spelunca fuit aliquando pravitatis haereticae"; Liber PontiPicalis I 312 .

43 Liber Pontificalis I 402-403. 
1 chorób kobiecych, święcąc w jej wspomnienie /5 II/ chleb, sól 1 wodę. Mimo tak szerokiego kultu w Polsce, nie poświęcono jej zbyt wielu, kościołów - w diecezji tarnowskiej nie ma aktualnie ani jednego. Jej częsta obecność w przydrożnych kapliczkach można przypisać głównie pobożnośc1 ludowej $i$ związanym z nią poświęceniom w dniu jej 11turgicznego wspomnienia.

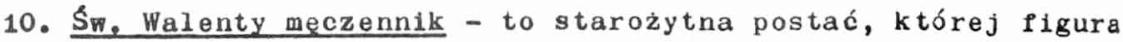
czesto zdobi polskie przydrożne kapliczk1. Mimo, że niegdyś należał do najbardziej znanych 1 czczonych świętych wościele Zachodnim, nie posiadamy o jego życiu prawie żadnych historycznych wiadomości, tak 1 z niektórzy powątpiewają nawet w jego faktyczne istnienie. W oparciu o późne Passiones /VI พ./, szczególnie "Passio Maris et Marthae" ${ }^{44}$ oraz martyrologia $a^{45}$ mial zostać jako kapłan rzymski ścięty podezas prześladowania za panowania Klaudiusza II Gota ok. $269 \mathrm{r}$. /14 II/. Te ostatnie mówią o dwóch Walentych - kapłanie rzymskim 1 biskupie Terni /Umbria/ - ale prawdopodobnie chodzi o tę samą postać, której kult przeniósł się z Terni do Rzymu. Mimo powyżzych luk historycznych jego kult odnotowywany jest od IV wieku. Nad jego grobem przy V1a Flaminia papiez Juliusz I /336-352/ wybudował bazy$11 \mathrm{keq}^{46}$, którą później odrestaurował papież Teodor I /642-649/, a papiez Damazy /366-384/ ułożł na jego cześć specjalny hymn ${ }^{47}$. Od tego czasu istnieja też katakumby jego imienia, a od VII w. jego podobizny, np. Presk w Santa Maria Antiqua z greckim podpisem /VIII w./, mozaika w bazylice św. Praksedy /IX w./. W średniowieczu kult Walentego rozprzestrzenił się po całej Europie mchłaniając w siebie wiele

44 Por. BHL n. 5543 1 8463; Acta SS. Februaril II 751-754; Skarga I 295-296; BS XII 896-897; LThK X 598-599; BCat XII 976-979; FrosSowa 446; Zalesk1 86-87; 0. Marucch1, La cripta sepolcrale di San Valentino sulia Via Flaninia rivenuta e descritta, Roma 1878 ; A. Amore, S. Valentino di Roma o di Terni, "Antonianum" 41/1966/ 260-277.

45 Martyrologium Hieronymianum 92-93: "Interamnes via Flaminia milia" rio ab urbe LXIII natale Valentini"; Martyroiogium Romanum 62, Turbak 62: "W Rzymie, przy drodze Flamińskiej, świętego Walentego, kapłana 1 męczennika. Uzdrowił wielu chorych $\mathbf{i}$ słynął z wielkiej nauki. Za panowania cesarza Klaudiusza obito go rózgami, a potem śc1ęto" / + 269/.

46 Por. Catalogus Romanorum Pontificum sub Liberio descriptus a. 354, PL 13, 453: "/Julius/ ... Pecit ... basilicam in Via Flaminia, milliario II, quae appellatur Valentini"; Liber Pontificalis I 332-333.

47 A. Ferrua, spigrammata Damasiana, dz.cyt., 197-200. 
zwyczajów ludowych. Pod wpływem Niemiec czczony był ogólnie jako p tron chroniący przed padaczką i chorobami nerwowymi, w Anglil zaś 1 Stanach Zjednoczonych uważa się go za patrona zakochanych. W Pol sce jegokult i imię, choć uważane za chłopskie, znane było od sch ku średniowiecza. Od tego czasu poświęcono mu wiele obrazów, ołtarzy, a także dawnych kościołów. Tak np. Wrobi, w archidiecezji poznaŕskiej posiadał kiedyś głośne sanktuarium z przechowywanymi relikwiami 1 obrazem słynącym łaskami. Jest także patronem diecezj przemyskiej. it diecezji tarnowskiej nie ma obecnie dedykowanego so. bie kościoła, choć w latach 1510-1761 istniał w Nowym Sączu kośció: szpitalny dla trędowatych fundowany/1464/przez radę miejską. Duż 11 ość jego wizerunków przydrożnych zdaje się mieć swe źródło w zwy. czajach ludowych, prywatnym nabożerstwie, 1 wimionach fundatorów.

11. Sw. Wiktoria, męczennicáa z Sabiny pod Rzymem-to rómniez starożtna postać, obecna w polskich kapliczkach przydrożnych. Nic jednak pewnego nie wiemy ani o rodzaju, ani o dacie jej męczeńskie; śmierci, którą miała ponieść razem ze św. Anatolią. Według zredagowanej w VII w. Passio, na podstawie innych akt męczeŕskich /Nereus? Achillesa, Parteniusza, Rufiny, Sekundy/, którą znał di parafrazował jeszcze Adelhelm $/+709 / 48$ oraz według martyrologíw miała zginąć /23 XII/ podczas prześladowań Decjusza 49 . Przyczyną jej śmierci była prawdopodobnie odmowa ręki rzymskiemu poganinowi, który urazony zdemaskował jej przynależność do chrześcijaństwa. Jej relikwio p wielu perypetiach znalazły sie w Subiaco. Pierwsze historyczne \$lad:

48 De laude virginum, PL 89, 279-280; De laudibus virginitatis 52, PL 89, 151-152; BS I 1074-1082; DHGE II 1501-1502; Skarga I 445446; Fros-Sowa 452; Zaleski 783-784; P. Paschini, La "Passio" delie martiri Sabine Vittoria ed Anatolia, Roma 1919.

49 Martyrologium Bedae. Appendix: Calendarium Anglicanum, PL 94, 1158: "X Kal. dec. Natale sanctorum Eusebi1, Joannis, Felicis et S. Victoriae martyris"; Martyrologium Romanum 597, Turbak 361: "W Rzymie podczas prześladowania cesarza Decjusza cierpienia świętej Wiktorii, panny 1 męczenniczki. Zaręczona z Eugentuszem poganinem, nie chciała ani go poślubić, ani złoży of ofiary bożkom, a równocześnie pozyskała mocą zdziałanych cudów wiele panien dla Chrystusa. Narzeczony wobec tego zażądał, aby kat przebił jej serce". 
jej kultu pochodzą dopiero z VI w., a poświadczone sa w Martyrologium Hieronymianum 50 w poświęconej jej mozaice w raweriskiej bazylice Sant'Apollinare Nuovo. W Polsce jej imię i kult znane sa od schyłku óredniowiecza, a wyrażają się głównie w licznych obrazach kościelnych. Do ich rozpowszechnienia przyczyniło się niewątpliwie przywiezienie do Polski w $1625 \mathrm{r}$. jej relikwii przez abpa gnieźnieńskiego Henryka Firleja 1 umieszczenie ich w koleglacie Matki Bożej Wniebowziętej w Lowiezu. Dz1ś kult jej zanikł, a nadawanie jej imienia należy do rzadkości. W diecezji tarnowskiej nie posiada dedykowanego soble kościoła i dziwi niewątpliwie duża liczba jej wizerunków przydrożnych, których źródła należy upatrywać głównie w imionach dawnych fundatorów.

12. Sw. Tekla - to inna starożytna święta, obecna w polskich kapliczkach przydrożnych. Według powstałych pod koniec II w. apokryficznych "Acta Pauli et Theclae", miała być uczennica $i$ towarzyszką św. Pawła, skazanł najpierw w Ikonium na spalenie, a gdy w cudowny sposób została ocalona, na pożarcie przez dzikie zwierzęta w Antiochii. Umarła ostatecznie w Seleucji /23 IX/, uzyskując tytuł "pierwszej męczennicy"51. Od początku wokół jej osoby powstało wiele fantastycznych opowieści, które surowo oceniali już Tertulian ${ }^{52}$, św. Hieronim ${ }^{53}$ i pseudo-Gelazy wykluczajazcy publiczne czytanie tych akt w kościele $e^{54}$. Pojawiła się nawet grupa uczonych, zaprzeczająca jej historycznemu istnieniu $i$ wyprowadzajaca jej kult z mitu o Artemidzie i Atenie ${ }^{55}$. Zbyt duża jednak ilość konkretnych źródłowych

50 Martyrologium Hieronymianum: "VI Idus tulii in Savinis Anatolie Victorie"; 19 XII: "In Savinis civitate Tribulana Victoriae".

51 Acta Pauli et Theclae, ed. R. A. Lipsius - M. Bonnet, Acta Apostolorum apocrypha, I, Lipsiae 1891, repr. Hildesheim 1959, 235-272; 0. Gebhardt, Passio $\mathrm{S}$. Theclae virginis/TU VII $2 /$, Le1pzig 1902; Acta SS. Septembris V 545-568; BHL II nn. 80208025; Skarga III 544-546; BS XII 176-177; Fros-Sowa 426; Zalesk1 564 .

52 Por. De baptismo 17, 5, CCL 1, 291-292, PSP 5, 150.

53 De viris illustribus 7 , PL 23, 619, PSP 6, 33.

54 De libris recipiendis et non recipiendis, PL 59, 177-178.

55 Por. E. Lucius, Die Anfange des Heiligenkults in der christlichen Kirche, Tubingen 1904, 205-214; V. Schultze, Altchristiche Stadte und Landschaften, II, Gutersioh 1926, 236-247. 
wzmianek nie pozwala na podtrzymanie takiej opinii. Niezwykle bujny 1 niewytłumaczalny rozwój jej kultu w staroźytnym, wschodnim 1 zachodnim chrześcijaństwie, związany z jej domniemanym grobem w izauryjskiej Seleucji, gdzie miała głośne sanktuarium, zaczyna się od IV wieku. Do jej rozgłosu przyczynił się też Bazyli z Seleucji /+ po 449/ przez dzieło "De vita ac miraculis Theclae virginis martyris" napisane ok, poł. V w., uzupełniajace apokryficzne "Acta Pauli et Theclae" 1 przekazujące wiele informacji o jej grobie, sanktuarium $i$ odbywanych do niej pielgrzymek ${ }^{56}$. Imię Tekla występuje często w greckich i łacińskich księgach liturgicznych, synaksariach, martyrologiach ${ }^{57}$ pismach ojców Kościoła, a jej wizerunki pojawiają sie od III w. /2 stare Preski w. Muzeum Biblioteki Watykańskiej/. Kult jej spowity nadal w bogate legendy $i$ fantastyczno opowieści był jeszcze źywy w średniowieczu,kiedy to stała się patronkę wielu kościołów, klasztorów 1 miast. Jej 1mię wączono do litanil za konających oraz czczono ja jako orędowniczkę w czasach zarazy 1 poźarów. Również w Polsce od średniowiecza św. Tekla cieszyła się zywym kultem, wyrazającym się nie tylko w uzywaniu jej imienia, ale 1 w dedykowanych jej kościołach 1 ołtarzach, a nawet w odwiedzanych przez pielgrzymki sanktuariach /np. w Dobrzycy w diecezjl poznańskiej/. W d̆iecezji tarnowskiej nie posiada obecnie zadnego dedykowanego sobie kościoła, a stosunkowo częsta jej obecność w kapliczkach przydrożnych zdaje się spoczywać głównie w imionach 1ch fundatorek /np. I wowa - obraz 1857, Wojakowa - rzeźba 1960/.

13. Śm. Helena - to ostatnia wreszcie starozytna święta spotykana często w przydroznych kapliczkach Podkarpacia. Mimo iz była matką cesarza Konstantyna wielkiego, bardzo mało posiadamy wiadomości o jej życiu. Z okresu patrystycznego informacji na jej temat

56 PG 85, 474-618; por. Peregrinatio Egeriae 22, 2-23, 5, SCh 296, 226-230.

57 Martyrologium Hieronywianum, ss. 110, 160, 486, 523-524, 655-656, 660; Martyrologium Romanum 412-413, Turbak 276: "W Ikonium, w Likaoni1, świętej 'rekl1, panny i męczenniczki. Dla wiary' pozyskał ja święty Paweł apostoł. Trwajizc niezłomnie we wierze Chrystusa przezwyciężyła za panowania Nerona mękę ognia 1 nie ulękła się dzikich zwierząt. Po wielu walkach, zniesionych dla zbudowania innych, udała się do Seleucji, gdzie zasnęła w pokoju. Ojcowie Kościoła uczcili ja wielkimi pochwałami"/I w. ?/。 
dostarczają: Euzebiusz z Cezarei, św. Ambroży, św. Paulin z Noli oraz historycy: Rufin, Sulpicjusz Sewer, Sokrates i Teodoret ${ }^{58}$. Urodzona w bityńskım Drepanum miała byé stajenną, którą poślubił Konstancjusz Chlorus, mając z nią następnie syna Konstantyna. Gdy ten został cesarzem nadał jej tytuł "najszlachetniejszej niewiasty" 1 "augusty", czyli cesarzowej oraz polecił bić monety z jej wizerunkiem $i$ napisem "Flavia Helena Augusta". W $326 / 324 /$ r podjęła pielgrzymkę do miejsc świętych w Palestynie, gdzie ufundowała bazyliki Narodzenia Pańskiego w Betlejem 1 Wniebowstąpienia na Górze 0liwnej; miała równiez odnaleźć drzewo Krzyża św. 1 narzędzia Męki Pańskiej na Golgocie. Fakt ten po raz pierwszy przypisuje jej พ 395 r. św. Ambroży 59 , a za nim Ruein, Sulpicjusz Sewer, Paulin z Nol1, Sokrates 1 Teodoret. Nie wspominaja jednak o tym współcześnl temu wydarzenlu, znający dobrze ówczesne realia palestyńskie, np.: Euzebiusz z Cezare1, Konstantyn Wielk160, zwiedzajacy w 337 . Golgotę pielgrzym z Bordeaux ${ }^{61}$, Cyryl Jerozolimski, będący pierwszym

58 Eusebius, Vita Constantini III 41-47, PG 20, 1101-1108; Ambrosius, De obitu Theodosi1 41-48; CSEL 73, 393-396, POK 21, 255260; Paulinus Nolanus, Epistola 31, 4-6, CSEL 29, 271-273; Rufinus, H. E. I 7-8, PL 21, 475-477; Sulpicius Severus, Chronica II 33-35, CSEL 1, 87-88; Socrates, H. E. I 17, PG 67, 117-122, tłum. S. Kazikowski/Sokrates Scholastyk, Historia Kóscioła, Warszawa 1972/, 63 - 66; Theodoretus, H. E. I 17, PG 82, 957962 ; por. również Hieronymus, Chronicon a. 306, GCS 47, 228, 21-25; Philostorius, H. E. II 16 b, GCS 21, 26-27; Orosius, H1storlae VII 25, 16, CSEL 5, 493; Gregorius Magnus, Epistolae XI 29, PG 77, 1142 A; Cassiodorus, Historia tripartita II 18, PL 69 , 936-937; Beda Venerabilis, Historia ecclesiastioa gentis Anglorum I 8, PL 95, 35; Zosimos, Historia nova II 8, 219,2 ; Eutropius, Breviarium $X 2,21$ IX 22 ; Acta SS. Augusti III, 548654; BS IV 988-995; DACL VI 2126-2145; ECat V 205-209; LThK V 208-209; Catholicisme V 574; Fros-Sowa 209-210; Zaleski 479-482; E. Zwolski, Helena matka Konstantyna Wielkiego w świetle historii, "Leszyty Naukowe KUL" 5/1962/z• 2, 53-76.

59 C. Favez, L'episode de l'invention de la Croix dans 1'oration funebre de Théodose par saint Ambroise, "Revue des Etudes Latines" 10/1932/423-429; J. Straubinger, Kreuzauffindungslegende, Paderborn 1913; A. Lisiecki, Konstantyn Wielki, Poznan 1913, 129132.

60 Por. Epistola ad Hacarium episcopuni, PG 67, 95-98, Kaz1kowski 49-51.

61 Itinerarium Burdigalense 593, 4-594, 4, CCL 175, 17 . 
autorem wczesnochrześcijańskim informującym / $351 \mathrm{r}$./ o znalezieniu krzyża w ogóle oraz o jego objawieniu się na niebie ${ }^{62}$, mówiąca o obchodach rocznicy znalezienıa krzyza w Jerozolimie galijska pątniczka Eger1a ${ }^{63}$, ani wreszcie św. Jan Chryzostom piszący /ok. $390 \mathrm{r} \cdot /$ o noszeniu przez wiernych cząsteczek znalezionego krzyża ${ }^{64}$. Odnalezienie krzyża przez Helenę wydaje się więc byé mało prawdopodobne, chociaż od V w. tradycyjnie jest przyjmowane. Zmarła w Nikomedil ok. 328 r., w wieku 80 lat, jej ciało pochowano najpierw w Konstantynopolu, a potem przewieziono do Rzymu, gdzie jej grób jako świętej, obok grobów męczenników, nawiedzali często pielgrzymi od VII wieku. Jej imię umieszczono wkrótce w martyrologiach pod data 18 sierpnia, choć Kościół Wschodn1 czci ją 21 maja razem z synem Konstantynem ${ }^{65}$. W średn1owieczu była patronka wytwórców igieł 1 gwo 4 dzi oraz farbiarzy. Za patronkę obrały ją sobie diecezje: trewirska, bamberska 1 bazylejska. Dedykowano jej tez w Europie wiele kościołów/w Angli1 ok. 120 kośclołów/. Również Polsce jej imię było znane 1 popularne od XIII w. ${ }^{66}$, chociaz niewiele poświęcono jej kościołów 1 ołtarzy. W diecezjl tarnowskiej znajduje się tylko jeden kościóx z 1686 r. w Nowym Sączu. Główne źródło licznego występowania jej wizerunków przydrożnych zdaje się tkwić w częstym nadawaniu imienia Heleny w tym regionie oraz $w$ jej patronacie nad niektórymi cechami rzemieślniczymi.

Reasumując, należy stwierdzić, że główną 1 zasadniczą przyczyną obecności pewnych śwlętych w kapliczkach przydroźnych był ogólnoeuropejski, ciągnący się przeważnie od średniowiecza, kult danego świętego, uważanego zwłaszcza za patrona lub protektora jakiejó dziedziny ludzkiego życia. Kult ten przeszczepiony na teren Podkarpacia miazze się często z rozmaitymi poświęcentami 1 zwyczajami ludowymi.

62 Epistola ad Constant1um imperatorem, PG 33, 1165-1176, tłum. W. Kania, Voxp 6/1986/z.10,292-296, spec. nota 2, s. 292-293.

63 Itinerarium Egeriae 36, 4-37, $3148,1, \operatorname{CCL} 175,88-89$, PSP $6,215-216,226$.

64 In Joannem hom. 8, 5, PG 59, 461; Contra Judaeos et gentes 10, PG 48, 826 .

65 Martyrologium Hierongmianum 450; Martyrologium komanum 346, Turbak 237: "W Rzymie przy drodze Lawikańskiej, swiętej Heleny, matki bogobojnego Konstantyna Wielkiego, który pierwszy dał wszystkim władcom wspaniały przykład, jak należy bronić Kościoła 1 jak go rozszerzać".

66 Slady jejkultu w Polsce por. Z. Obertyńsk1, Pontyfikały krakowskie XV w1eku, PK 4/1961/370-371. 
W niektórych wypadkach trudno jest wytłumaczyć obecność danego świętego. Olnosi się to szczególnie do ojców Kości oła, których kultu nie było. Ich występowanie może być uzasadniane wolą fundatorów kapliczek, unieszczających w nich wizerunki swoich patronów.

Na koniec należy wyrazić życzenie, ażeby inne diecezje, podobnie jak diecezja tarnowska, opracowały katalogi wszystkich kapliczek przydroznych 1 figur, zwłaszcza tych zmurszałych i pokrytych patyną czasu, aby zachować przynajmniej pisane świadectwo o dziedzictwie chrześcijańskim dla przyszłych pokoleń.

\section{Alicja Stepniewska - Lublin}

\section{L'ANTIQUITE CHRETIENNE DANS LES CHAPELLES DU BOID DE LA ROUTE /Résumé/}

L'article se compose de deux parties principales. Dans la premiére, à la base du livre "Kapliczki, figury i krzyże przydrożne na terenie diecezji tarnowskiej"/= Chapelles, figures, croix du bord de la route dans le diocese de Tarnów $=/ / 1983 /$, i auteur nous 1ndique lesquels des saints antiques/il y en a aussi les Péres de $1 \mathrm{Eglise/,} \mathrm{a} \mathrm{quelle} \mathrm{eréquence} \mathrm{et} \mathrm{sous} \mathrm{quelle} \mathrm{forme/figure,} \mathrm{bas-re-}$ lief, peinture/ sont presentés dans les chapelles du diocése de Tarnów.

Dans la deuxj’eme partie, l'auteur tâche de,justifier l'existence de 13 saints presentes le plus souvent/jusqu'a 15 fois/ - St Florien, Ste Barbe, Sțe Agnès, Ste Sophie avec ses filles, St Laurent, St Martin, St Sébastien, Ste Agathe, St Victoire, Ste, Thècle, Ste Hélène - en montrant leur culte incessant de 1 Antiquité jusqu'à nos jours. 